\section{FIRST POOR-WILL SPECIMEN FOR SASKATCHEWAN TAKEN}

On August 22, 1961, Bruce McCorquodale and Albert E. Swanston of the Saskatchewan Museum of Natural History collected a male Poor-will (Phalaenoptilus nuttalli) about one-quarter of a mile south of the Museum's paleontological camp on Calf Creek in southwestern Saskatchewan (specimen in S.M.N.H.). Previously, birds had been heard calling, and McCorquodale reported 15 separate sightings in different locations that he felt could have represented at least six different birds. The birds observed would first settle on the ground and then, when flushed, would fly away in an erratic flight which was difficult to follow. The characteristic "poor-will" call was given from the top of a spruce tree. When the bird was on the ground, iMcCorquodale and Swanston could imitate its soft "whick, whick" call note and the bird would fly up and circle around them.

I have visited the paleontological field camp at this season for several years, and have never noted the Poor-will. The only sound I have heard near the camp is the typical nighthawk call. It is also interesting that the party working in the Cypress Hills area with W. Earl Godfrey did not record it there in June-July, 1948 (Godfrey, 1950, Birds of the Cypress Hills and Flotten Lake regions, Saskatchewan).

The Poor-will has been listed on the Field check-list of Saskatchewan Birds (1959) as a hypothetical species on the basis of observations reported by H. H. Mitchell (1924. Catalogue of the birds of Saskatchewan. Can. Field-Nat. 38:111) -one recorded by L. B. Potter at Eastend in June, 1905, and another reported seen at the south end of Last Mountain Lake, by C. H. Young, 1920.-Fred G. Bard S.M.N.H.

\section{MOURNING DOVE AT NEILBURG, SASKATCHEWAN}

I should like to know how far north in Saskatchewan the Mourn- ing dove occurs. We live at Neilburg, about 80 miles west of North Battleford, and I do not recall seeing doves in our district before this year. On June 9, 1961, however, I am sure I saw ind heard a Mourning Dove. Hearing the bird, I went to the front door and looked out at it sitting on the telephone wire where I could see the rosy breast, slim body and long iail. When it flew, I could see white on either side of the outspread tail. In short, the bird looked exactly like the picture of the Mourning Dove in Taverner's Canadian Land Birds, which I checked.

-Mrs, J. E. Meagher, Neilburg, Sask

EDITOR'S NOTE: Since Neilburg is near the Alberta border, Mrs. Meagher will be interasited in the range for the Mcurning Dove in Alberta defined by Salt and Wilk in The Birds of Alberta (1958): "oocurs rarely in northern Alberta at least as far as Ft. Vermilian and Ft. Chipewyan." Dr. Nero did not recond the Mourning Dove in the summers of 1960 and 1961 at Lake Athabasca on the Saskatriherwan side of the bonder. but he ncted three at Ia Ronge on August $i$ of this year. Anyone $w_{i}$ ith interesting northern records of the Mcurning Dore should write to Bernard Gollap, Canadian Wildlife Siervice, Saskatoon, as Mr. Crollop is making a survey of Mourning Doves for the Service.

\section{SLATE-COLORED JUNCO NESTING AT SPIRIT LAKE}

Mention of a search for a junco nest along the Saskatchewan River during the recent summer meeting of the Saskatchewan Natural History Society reminded me of a local nest record ror this species. The nest was located on May 31, 1953, near a trail along the edge of a willow grove. The nest was on the ground partly beneath a fallen limb. In the nest were three eggs of the Brownheaded Cow'bird and one Slatecolored Junco egg. One cowbird egg was removed on June 5 and a second on June 7 . On June 21 the nest contained one young junco and one young cowbird. The cowbird was more than twice the size of its nest mate; it was removed. The nest was empty on June 25. On July 2 two juncos were noted about 400 yards from the nest site - apparently an adult and an immature. - William Anaka, Spirit Lake. .

EDITOR'S NOTE: No breeding records are cited for the Yorkton area in Stuart Houston's list (1949. The birds of the Yorkton district, Saskatchewan. Can. Field-Nat. 63:215-241). 